\title{
Catalysis by Candida antarctica B (CALB) immobilized on natural pure silica by adsorption: comparison with the free enzyme
}

\author{
Djossou A.Ja, Mazoua M, Toukourou A.Cb, Tchobo F.Pa, Blin Jc, Yao K.Bd, Soumanou M.Ma \\ a Unité de Recherche en Génie Enzymatique et Alimentaire, Laboratoire d'Étude et de Recherche en Chimie Appliquée, \\ École Polytechnique d'Abomey-Calavi, Université d'Abomey-Calavi, 01 BP 2009 Cotonou, Bénin. \\ b Laboratoire d'Énergétique et de Mécanique Appliquée (LEMA), École Polytechnique d'Abomey-Calavi, 01 BP 2009 \\ Cotonou, Benin \\ c Unité Mixte de Recherche Ingénierie des Agropolymères et Technologies Émergent (UMRIATE/ CIRAD), 73 rue Jean- \\ François Breton, 34398 Montpellier Cedex 5, France. \\ d Laboratoire de Procédés Industriels, de Synthèse, de l'Environnement et des Énergies Nouvelles, INP-HB de \\ Yamoussoukro, BP 1093 Yamoussoukro, Côte d'Ivoire. \\ Auteur correspondant: msoumanoufr@yahoo.fr, mohamed.soumanou@epac.uac.bj
}

Original submitted in on $24^{\text {th }}$ September 2016. Published online at www.m.elewa.org on $30^{\text {th }}$ November 2016 http://dx.doi.org/10.4314/jab.v107i1.8

\begin{abstract}
Objective: In this work, a lipase B from Candida antarctica strain was immobilized onto natural silica carriers via adsorption to enhance its feasibility in practical applications.

Methodology and results: The biocatalyst was prepared by simple adsorption on the support whose composition was beforehand characterized and the activities in ethyl ester hydrolysis and synthesis evaluated. The natural silica carriers were rich in silicon dioxide $\left(\mathrm{SiO}_{2}\right)(97.36 \%)$. The optimum temperature of immobilized lipase was $40^{\circ} \mathrm{C}$, which was identical to that of the free enzyme. The immobilized lipase exhibited a higher relative activity than that of free lipase over $40^{\circ} \mathrm{C}$. The optimal pH for immobilized lipase was 7.5 , which was similar to that of the free enzyme. After 10 recycled batches, a high residual esterification conversion (90\%) was maintained.

Conclusions and application of findings: The results in the present work indicate that pure silica is a potential material as an immobilization matrix for industrial process. There may have a promising future as support of the biocatalysts in various syntheses.
\end{abstract}

Key words: Lipase immobilization, adsorption, Candida Antarctica, natural silica.

\section{INTRODUCTION}

Lipase (triacylglycerol ester hydrolases, EC 3.1.1.3) is an important enzyme with a broad variety of industrial applications due to the multiplicity of reactions, which it catalyzes, with a broad variety of applications in fine chemistry, pharmaceutical industry and in the food industry owing to their usefulness in both hydrolytic and synthetic reactions (Sharma et al., 2001; Monier et al., 2010). Several works were carried out these last years to obtain immobilized lipase derivatives suitable for different reactions. An immobilized enzyme is defined as the enzyme physically confined to a certain defined 
region while retaining its most catalytic activity (Jegannathan et al., 2008). Among the several methods of immobilization, adsorption is the method, which induces less modification on the active conformation of the enzymes. Consequently, adsorption is one of the methods preferred for the immobilization of enzymes. In this method, enzyme fixation is performed through hydrogen bonds, salt linkages, and Van der Waal's Forces. The use of phyllosilicates, mainly sepiolite, to immobilize enzymes was described; nevertheless, silicate-type materials have been usually used in a two-step covalent immobilization method, which involves the previous activation of the clay and a posterior covalent binding of the enzyme. The use of silicates as lipase carriers presents numerous advantages, such as the high specific surface available between (200 and $800 \mathrm{~m} 2 / \mathrm{g}$ ), the facility of water dispersion recuperation, the high water uptake capacity and the excellent mechanical resistance of these materials. Their natural origin and low cost make them even more attractive from an applied point of view. Efficiency and recyclability of immobilized enzymes depend not only on the procedure and support utilized but also on the specific enzyme used and the

\section{MATERIALS AND METHODS}

Chemicals: Lipase powder from Candida antarctica B was used as enzymes. Oleic acid and Jatropha curcas oil were used as substrate triglyceride. Ethanol was used for reaction. The oleic acid was bought and Jatropha curcas oils were obtained by the method of Soxhlet at the laboratory. Other chemicals and solvents were obtained from Chemical Company (Sigma Aldrich).

Characterization of support: Silica was crushed by a vibro-crusher (SIMENS SIMATIC BREADS 2) for 30 second. The loss on the ignition of the samples were determined by calcination with the furnace with $975 \mathrm{C}( \pm$ 25 ) during one hour to return the samples dryness before the analysis. The density was determined by the densimeter of Chatelier. The chemical composition of natural support rich in silica is determined with a spectrophotometer with ray-X (THERMO SCIENTIFIC, ARL OPTIM' X, WDXRF Spectrometer)

Immobilization of lipase: For immobilization in aqueous media $150 \mathrm{mg}$ lipase was dissolved in $5 \mathrm{ml}$ of sodium phosphates buffer $(0,1 \mathrm{~mol} / \mathrm{L}, \mathrm{pH} 7,3)$ and centrifuged at $2400 \times \mathrm{g}$ for $3 \mathrm{~min}$ to remove insoluble components. The type of process where it is applied (Li et al., 2013). Various immobilization procedures like adsorption, cross-linking, encapsulation or entrapment have been employed on lipases used for biodiesel production (Jegannathan et al., 2008). However, most immobilization procedures use sophisticated protocols for lipase entrapment on expensive supports (Ferrer et al., 2002) not suitable for a real scale-up, causing an increase in the costs of industrial processes. Therefore, adsorption, used in this work, is a suitable system for lipase immobilization that could be successfully applied to large volume industrial processes, as in biodiesel production, because of its simplicity and low cost (Cesarini et al., 2014). This type of immobilization occurs via binding of the lipase onto the surface of the support by weak forces, such as Van der Waals or hydrophobic interactions or through dispersion forces.In this study, the physical adsorption of Candida antarctica B onto natural support rich in silica is described. The stability and the activity of the immobilized lipase were also investigated. Finally, the reusability of this immobilized lipase was tested.

supernatant $(4 \mathrm{ml})$ was mixed with pure silica $(250 \mathrm{mg})$ under low stirring for $12 \mathrm{~h}$ at room temperature. The particles were filtered under reduced pressure and washed with the same buffer under reduced pressure, and then one dried at room temperature. Consequently, the residue was obtained which is immobilized lipase on support. The immobilization efficiency was evaluated in terms of protein yields by measuring the difference between the protein concentration in the lipase solution before and after immobilization according to the following equation:

Protein immobilization yield $(\%)=(\mathrm{Ci}-\mathrm{Cf}) / \mathrm{Ci}$

where $\mathrm{Ci}$ is the initial protein concentration in the lipase solution, and Cf is the final protein concentration in solution after immobilization. The protein concentration was measured according to the method using bovine serum albumin (BSA) as the standard (Wrolstad 2000). Hydrolytic activity: The hydrolytic activities of free and immobilized lipase were assayed by the palm oil emulsion method, according to the modification proposed by Soares et al. (Soares et al., 1999). The reactions of 
hydrolysis of free and immobilized lipases were performed in screw-capped flasks containing $1 \mathrm{~g}$ oil diluted in $5 \mathrm{ml}$ of Cyclohexane to which one adds $20 \mu \mathrm{L}$ of a calcium chloride solution $(0,2 \mathrm{M})$ and $50 \mu \mathrm{L}$ of the enzymatic solution (3mg/L) prepared in sodium phosphates buffer $(\mathrm{pH}=7)$. The mixture thus obtained was mixed under stirring $(300 \mathrm{rpm})$ for $30 \mathrm{mn}$ at room temperature. The reaction stops when one adds $3.5 \mathrm{ml}$ of an ethanol/acetone mixture. Free acidity is titrated $(\mathrm{V})$ with a solution welds $(C)$ in the presence of phenolphthalein against a white (Vo) without enzyme. The enzymatic activity (AE) is expressed in mole of free fatty acids which releases one $\mathrm{mg}$ of enzyme for unit of time $(\mathrm{T} ; \mathrm{mn})$ according to the following formula: $\mathrm{AE}=(\mathrm{C}(\mathrm{V}$ Vo)) $/(m \times t)$, with $m$ mass of enzyme in the enzymatic solution.

Esterification assay: The esterification reactions were performed in screw-capped flasks with a molar ratio of oleic acid to ethanol 1:1 $(0.4 \mathrm{mmol}$ of oleic acid and 0.8 $\mathrm{mmol}$ of ethanol), of immobilized lipase dissolved in $4 \mathrm{ml}$ of anhydrous $n$-hexane. The reaction mixture was shaken for $8 \mathrm{~h}$ at $220 \mathrm{rpm}$ at $37^{\circ} \mathrm{C}$ in a shaking incubator. Aliquots of $200 \mu \mathrm{l}$ were withdrawn periodically from the reaction mixture. The immobilized enzyme was removed by centrifugation at $2000 \mathrm{rpm}$ for $5 \mathrm{~min}$, and then the supernatant residual acids contents were assayed by titration with $0.5 \mathrm{~N}$ sodium hydroxide, using phenolphthalein as an indicator and $2 \mathrm{ml}$ of ethanol as a quenching agent. The conversion (\%) in ester synthesis was based on acid consumed (Bovora et al. 1993).

Enzymatic synthesis of biodiesel: The enzymatic transesterification reactions were carried out in a $50-\mathrm{mL}$ shaking flask under magnetic stirring at $180 \mathrm{rpm}$ at $40^{\circ} \mathrm{C}$ for $48 \mathrm{~h}$, using a ratio (Jatropha curcas oil: ethanol) = $(1: 10)$; free or immobilized lipase $=5 \%$ of Jatropha curcas oil. The ethyl ester contents in the reaction mixture were quantified using a GC-2010 gas chromatograph.

\section{RESULTS AND DISCUSSION}

Activated carbons are among the most effective adsorbents, having high surface area per unit mass (Yesiloglu 2005). Due to the relatively high cost of activated carbons, there have been attempts to utilize low cost, naturally occurring adsorbents for immobilization. In recent years, there has been increasing interest in utilizing natural clay minerals like montmorillonite (Ramos et al., 2014), bentonite (Yesiloglu 2005), and sepiolite (Myriam et al.,1998) or natural polymers (Lv et al., 2008, Ittrat et al.,2014, Pereira et al.,2003, Ramani et al.,2010) can also be used as support for the immobilization of enzyme. They are natural matrices resulting from
Effect of temperature on the free and the immobilized lipase activities: The effect of temperature on the relative activity of the free and immobilized CALB was determined at $\mathrm{pH} 8.5$ in temperature range varying from 25 to $50 \mathrm{C}$, oleic acid oil emulsion as substrate. Relative activities were calculated as the ratio of the enzyme activity measured at different temperatures to the maximal activity of the enzyme measured as described above.

Effect of $\mathrm{pH}$ on the free and the immobilized lipases activities: The effect of $\mathrm{pH}$ on the free and immobilized lipase activities was studied in $\mathrm{pH}$ range varying from 7.5 to 11 at $37 \circ \mathrm{C}$ using olive oil emulsion as substrate by using different buffers: glycine- $\mathrm{HCl} 50 \mathrm{mM}(\mathrm{pH} 3-4)$, sodium acetate $50 \mathrm{mM}(\mathrm{pH} 5-6)$, phosphate $50 \mathrm{mM}(\mathrm{pH}$ 7), Tris- $\mathrm{HCl} 50 \mathrm{mM}$ (pH 8-9) and boric acid $50 \mathrm{mM}(\mathrm{pH}$ 10-12). Relative activities were calculated as the ratio of the activity of enzyme measured at different $\mathrm{pH}$ to the maximal activity of enzyme, at $\mathrm{pH} 8.5$ and $37 \circ \mathrm{C}$.

Reusability of the immobilized Candida antartica B lipase: The esterification of oleic acid with ethanol was conducted under these conditions (ethanol /oleic acid molar ratio equal to 1; enzyme; hexane volume of $3 \mathrm{ml}$ and reaction time of $8 \mathrm{~h}$ ) using lipase immobilized. This immobilized CALB was reused many times for consecutive cycles. At the end of each batch, the immobilized lipase was removed from the reaction medium, washed with $\mathrm{n}$-hexane in order to remove any substrate or product retained in the support and dried at room temperature. Then, the immobilized lipase was used again for another reaction cycle using fresh substrates. Statistical analysis: Experimental results were given as mean value $\pm S D$ of three parallel measurements. All statistical analysis was conducted using Microsoft Excel and software SPSS version 14.0 for the analysis of the variance was used for the comparison of the average.

agricultural waste, which contain cellulose, hemicellulose and lignin for this process. Silica exists in the natural form in the world. In this work, it was used as support of immobilization considering its adsorbing character and its availability.

Chemical composition of pure silica and activity: The chemical composition of pure silica, as determined by spectrophotometer ray- $X$, was $\mathrm{SiO} 2(97.36 \%)$, aluminium oxide $\left(\mathrm{Al}_{2} \mathrm{O}_{3}\right)(1.12 \%)$, magnesium oxide $(\mathrm{MgO})(0.01 \%)$, (calcium oxide) $\mathrm{CaO}(0.22 \%)$, iron oxide ( $\mathrm{Fe} 2 \mathrm{O} 3$ ) $(0.53 \%)$, sodium oxide $\left(\mathrm{Na}_{2} \mathrm{O}_{3}\right)(0.03 \%)$, titanium oxide (TiO2). The silica content comparable with that is 
contained in bentonite support (70 - $80 \%$ ) (Yesiloglu 2005), and largely higher than is contained of montmorillonite (50-60\%) (Ramos et al., 2014), sepiolite (69.1\%) and the palygorskite (70\%) (Myriam et al., 1998). Table 1 presents the results of immobilization and the free and immobilized lipase acitivity. The enzyme immobilized on pure silica showed the same protein immobilization yield of $42.63 \%$ approximately. The hydrolytic activity values were $5.94 \mu \mathrm{mol} /$ ( $\mathrm{mg} \mathrm{min}$ and $2.33-\mu \mathrm{mol} / \mathrm{mg} \mathrm{min}$ respectively for free and immobilization enzymes while the esterification activity were $91.70 \%$ and $41.54 \%$ of oleic conversion.

Tableau 1: Immobilization yield and activity

\begin{tabular}{|c|c|c|c|c|c|c|}
\hline & $\begin{array}{c}\text { mg of } \\
\text { added } \\
\text { protein/g } \\
\text { of support }\end{array}$ & $\begin{array}{l}\text { Loading (mg of } \\
\text { added protein } \\
\text { fixed /g of } \\
\text { support) }\end{array}$ & $\begin{array}{c}\% \text { of } \\
\text { immobilization }\end{array}$ & $\begin{array}{l}\text { Hydrolytic } \\
\text { activity } \\
(\mu \mathrm{mol} /(\mathrm{mg} \\
\text { min)) }\end{array}$ & $\begin{array}{c}\text { Esterification } \\
\left.\text { activity* }^{*} \%\right)\end{array}$ & $\begin{array}{c}\text { Trans- } \\
\text { esterification } \\
\text { activity }^{* *}(\%)\end{array}$ \\
\hline CALB free & - & - & - & $5.94 \pm 0.1 a$ & $91.70 \pm 1.2 a$ & $90.40 \pm 1.2 a$ \\
\hline $\begin{array}{l}\text { CALB } \\
\text { immobilized }\end{array}$ & $42.63 \pm 1.1$ & $22.41 \pm 0.5$ & $52.56 \pm 1.5$ & $2.33 \pm 0.05 b$ & $41.54 \pm 0.8 b$ & $44.08 \pm 0.8 b$ \\
\hline
\end{tabular}

Biochemical properties of free and immobilized lipase $\mathrm{pH}$ stability and optimum pH: The effect of $\mathrm{pH}$ on the stability of both free and immobilized lipase was determined by measuring the residual conversion of oleic acid in the $\mathrm{pH}$ range of $6.0-8.0$ and the results were presented in figure 1 . The $\mathrm{pH}$ profiles of the immobilized lipases were broader than that of the free enzyme.
Furthermore, the optimum $\mathrm{pH}$ of the immobilized lipase was at $\mathrm{pH} 7.0-8.0$, while the optimum $\mathrm{pH}$ of free lipase was at 7.0. The retained activity of the immobilized enzyme was improved both at lower and higher $\mathrm{pH}$ in comparison to the free enzyme. The results show that the immobilization methods preserved the enzyme activity over a wider $\mathrm{pH}$ range.

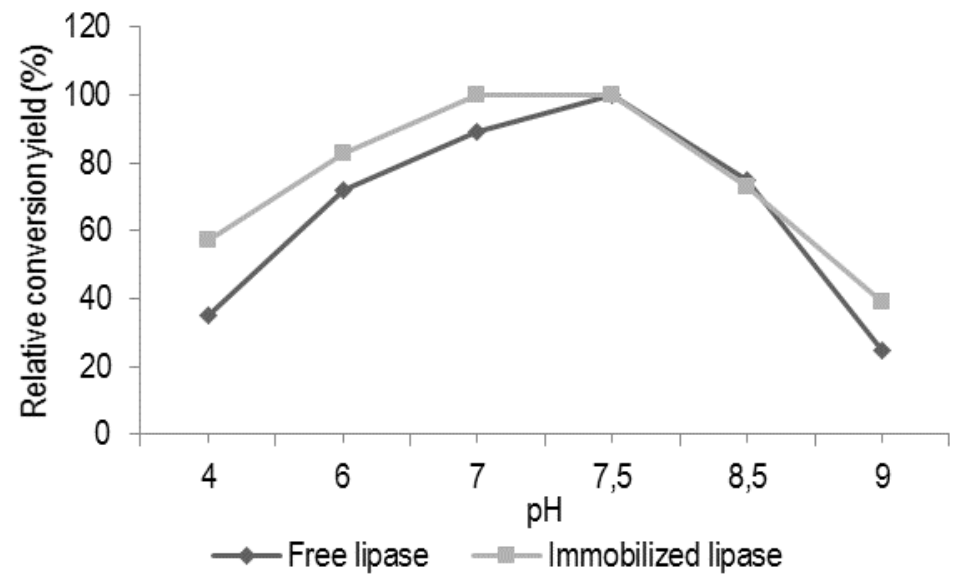

Figure 1: Effect of $\mathrm{pH}$ on lipase activity

Thermal stability: The immobilization of lipases onto solid support contributes to increase their thermostability and to extend their biotechnology potential, since running bioprocesses at elevated temperature is advantageous (Hasan et al., 2006). Both of the thermal stability of the free and the immobilized lipase was determined by measuring the residual conversion of oleic acid at $37^{\circ} \mathrm{C}$ after the enzyme exposed to temperatures ranging from 37 to $60^{\circ} \mathrm{C}$ in phosphate buffer $(0.1 \mathrm{M}, \mathrm{pH} 7.5)$ for $30 \mathrm{~min}$ (figure 2). As observed in Figure. 2, the free and the immobilized enzyme exhibited different temperature profiles. The immobilized lipase was stable at $30^{\circ} \mathrm{C}$, while the activity of the free enzyme was decreased drastically. The results also showed that the immobilized enzyme had more than $70 \%$ activity at $40^{\circ} \mathrm{C}$, while the free enzyme had only $30 \%$ activity. Thus, the immobilized lipase was much more stable than the free enzymes at higher temperatures. 


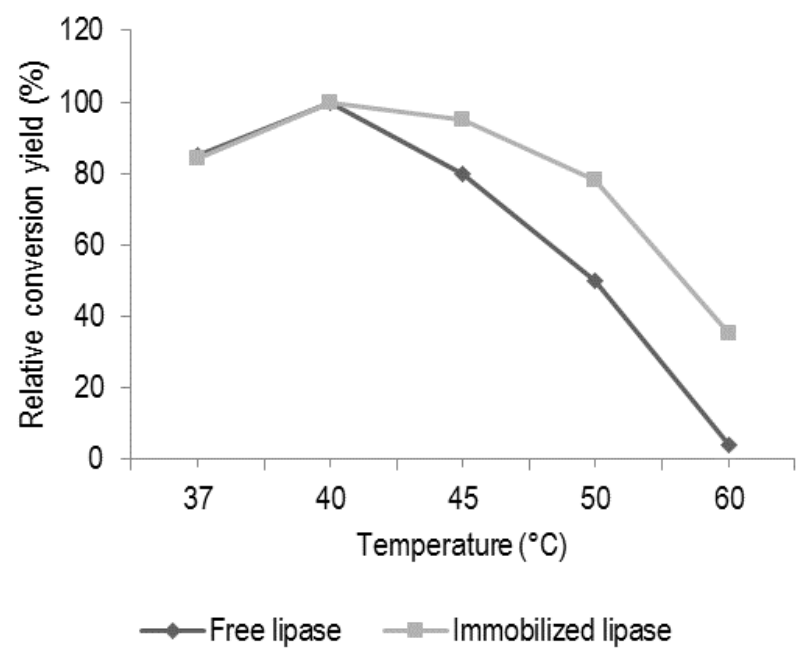

Figure 2: Effect of temperature on lipase activity

Reusability of the immobilized $C$ antartica lipase: The main advantage of immobilization of an enzyme is that an expensive enzyme can be repeatedly used (Iso et al., 2001).Immobilized lipase was used repeatedly by measuring the residual conversion of oleic acid at $37^{\circ} \mathrm{C}$ for $12 \mathrm{~h}$ and the reusability was examined because of its importance for repeated applications in a batch or a continuous reactor. As shown in figure 3, lipase immobilized displayed a good reusability. The analysis of this figure shows a significant reduction in approximately
$15 \%$ with the second use. This contact was also observed by several authors (Iso et al., 2001). When an immobilized enzyme was used for the first time, some amount of enzymes was desorbed. The desorption of an enzyme could not be observed after further repeated use. After 10 recycled batches, a high residual esterification conversion (70\%) was maintained. This confirms the remarks of Bai et al., (2006) which show that the lipase immobilized on the supports mesoporous of silica $\left(\mathrm{SiO}_{2}\right)$ exhibit good thermal stability and reusability.

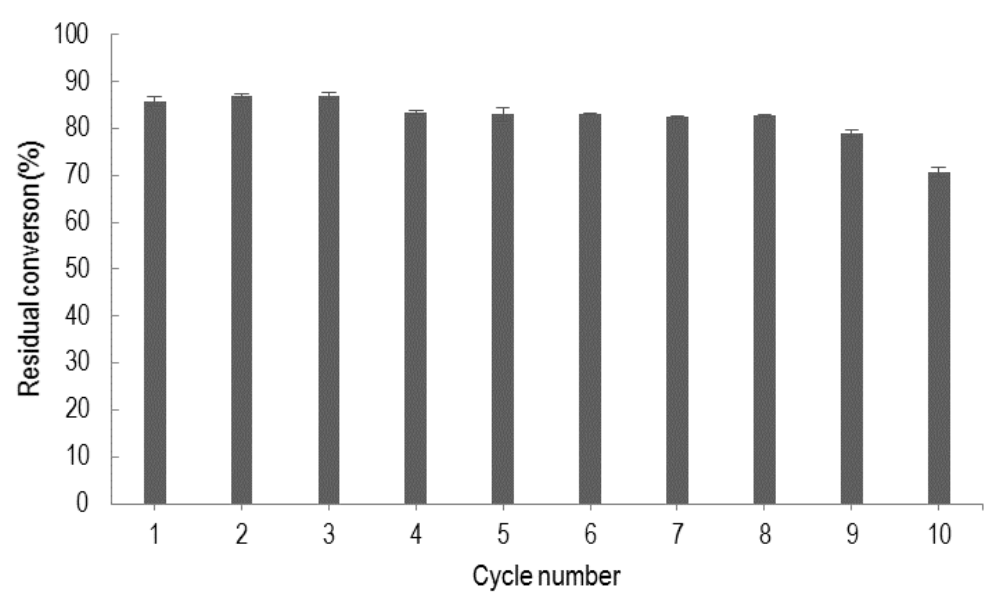

Figure 3: Effect of repeated use of immobilized lipase on the conversion of oleic acid

\section{CONCLUSION}

The results of the present study indicate that natural pure silica might be used as a support for Candida antartctica B. Immobilization of lipase can be carried out simply by direct deposition of the enzyme solution onto pure silica suspended in solvent free medium. Although enzymatic activity retained in the immobilized lipase (42\%) was not impressive but it was comparable to many inorganic support materials. Results obtained in this work can 
contribute to the development of immobilization processes of lipases using low-cost supports. Proper treatment of this support would undoubtedly improve its quality for use as supporting material for lipase immobilization. Thus, we recommend that more investigation, in the characterization of the adsorbent supports naturalness, is to realize in order to identify those, which can be used as supports of biocatalysts in several fields.

\section{ACKNOWLEDGEMENT}

This publication was prepared with the assistance of PRONOVABIO and AUF. The African Union and the European Union were gratefully acknowledged.

\section{REFERENCES}

Bai YX, Li YF, Yang Y, Yi LX, 2006. Covalent Immobilization of Triacylglycerol lipase onto Functionalized Novel Mesoporous Silica Supports. J. Biotechnol 125: 574 - 582.

Bovara R, Carrea G, Oottolina, G and Riva S, 1993. Effects of water activity on Vmax and $\mathrm{Km}$ of lipase catalyzed transesterification in organic media. Biotechnology Letters 15: 937-942.

Brady CL, Matcalfe D, Stahoszewski D, Frank D, 1988. Lipase immobilized on a hydrophobic microporous support for the hydrolysis of fats. $J$ Am Oil Chem Soc 65:917-921.

Cesarini S, Pastor FIJ, Diaz P, 2014: Improvement of $P$. aeruginosa $42 \mathrm{~A} 2$ lipase preparations for FAMEs production, both in immobilized and soluble form. J Mol Catal B Enzym 99:1-7.

Ferrer M, Plou FJ, Fuentes G, Cruces MA, Andersen L, Kirk O, Christensen M, Ballesteros A, 2002. Effect of the immobilization method of lipase from Thermomyces lanuginosus on sucrose acylation. Biocatal Biotransform 20: 63-71.

Hasan F, Ali Shah A, Hameed A, 2006. Industrial applications of microbial lipases. Enzyme Microbiol Technol, 39:235-51.

Iso M, Chen B, Eguchi M, Kudo T, Shrestha S, 2001. Production of biodiesel fuel from triglycerides and alcohol using immobilized lipase. J Mol Catal B: Enzyme 16:53-61.

Ittrat P, Chacho T, Pholprayoon J, Suttiwarayanon N, Charoenpanich J, 2014. Application of agriculture waste as a support for lipase immobilization. Biocatalysis and Agricultural Biotechnology 3: 72 - 82.

Monier M, El-Sokkary AMA, Sarhan AA, 2010. Immobilization of Candida rugosa lipase on modified natural wool fibers. Sarhan Reactive and Functional Polymers 70: 122 - 128.

Jegannathan KR, Abang S, Poncelet D, Chan ES, Ravindra P, 2008. Production of biodiesel using immobilized lipase - A critical review. Crit Rev Biotechnol 28:253-264.

Li X, Huang SS, Xu L, Yan YJ, 2013. Improving activity and enantioselectivity of lipase via immobilization on macroporous resin for resolution of racemic1-phenylethanol in nonaqueous medium. BMC Biotechnol 13: 1-9.

Lv P, Wang X, Yuan Z, Tan T, 2008. Conversion of Soybean Oil to Biodiesel Fuel with Immobilized Candida Lipase on Textile Cloth, Energy Sources, Part A: Recovery, Utilization and Environmental Effects 30:872- 879.

Myriam M, Suarez M, Martin-Pozas JM, 1998. Structural and textural modifications of palygorskite and sepiolite Under Acid Treatment. Clays and Clay Minerals 46:225-231.

Pereira EB, Zanin GM, Castro HF, 2003. Immobilization and catalytic properties of lipase on chitosan for hydrolysis and esterification reactions, Brazilian Journal of Chemical Engineering 20:343-355.

Ramani K, Boopathy RV, Kennedy JL, 2010. Immobilisation of Pseudomonas gessardii acidic lipase derived from beef tallow onto mesoporous activated carbon and its application on hydrolysis of olive oil. Process Biochemistry 45:986-992.

Ramos MD, Gómez GIG, González NS, 2014. Immobilization of Candida rugosa lipase on bentonite modified with benzyltriethylammonium chloride, Journal of Molecular Catalysis B: Enzymatic 99:79-84.

Sharma R, Chisti Y, Banerjee UC, 2001. Production, purification, characterization and applications of lipases. Biotechnol Adv 19:627-62.

Soares CMF, de Castro HF, de Moraes FF, Zanin GM, 1999. Characterization and Utilization of Candida rugosa Lipase Immobilized on Controlled Pore Silica, Applied Biochemistry and Biotechnology 77:45-757. 
Djossou et al., J. Appl. Biosci. 2016. Catalysis by Candida antarctica B (CALB) immobilized on natural pure silica by adsorption: comparison with the free enzyme

Wrolstad RE, 2000. Anthocyanins. In F. J. Francis, \& G. Yesiloglu Y, 2005. Utilization of bentonite as a support J. Lauro (Eds). Natural Food Colorants, New York 237-252. material for immobilization of Candida rugosa lipase. Process Biochemistry 40:2155-2159. 